\title{
OLD FAITHFUL VISITORS CENTER EXHIBIT OBSERVATION STUDY
}

\author{
PAT STEPHENS WILliams $\uparrow$ RAY DARVILle $\uparrow$ SARAH FUlLER $\uparrow$ ARTHUR TEMPLE \\ COLLEGE OF FORESTRY AND AGRICULTURE $\downarrow$ STEPHEN F. AUSTIN STATE UNIVERSITY \\ NACOGODCHES, TX
}

\section{$\downarrow$ OBJECTIVES}

This report was a result of volunteer research orchestrated by Katy Duffy, Interpretive Planner, Yellowstone National Park. The data collection was a direct need for grant compliance for the National Science Foundation associated with exhibits for the new Old Faithful Visitor Education Center, which opened to the public in August, 2006. The objective of this research was to understand visitor interaction with these exhibits using an unobtrusive form of data collection.

\section{$\downarrow \quad$ METHODS}

Volunteer researchers from Stephen F. Austin State University met with Ms. Duffy, Ms. Linda Young, Ms. Tami Blackford, and Ms. Rebecca Garoville at a conference room at the Park Headquarters in Mammoth Hot Springs on Monday, July 22, 2013. Discussions had already taken place between Ms. Duffy and Ms. Linda Young and Dr. Pat Stephens Williams prior to the trip to Yellowstone.

The data collection site was the Old Faithful Visitor Education Center (OFVEC) opened in August, 2006. The Visitor Education Center, located nearby to Old Faithful itself contains an information desk, exhibit hall, Yellowstone Association Store, an auditorium for Yellowstone videos, restrooms, and offices. Each day park staff count the number of visitors to the OFVEC using an electronic counter mounted at each of the Center's three entrances. During July $26^{\text {th }}$ the official count was 9,125 visitors while 8,035 were counted during the 8 a.m. to 8 p.m. time period in which the Center is open to the public. For Friday, July $26^{\text {th }}, 3.3 \%(302 / 9125)$ of visitors were studied in the Exhibit area while on Saturday, July $27^{\text {th }}$, $2.6 \%(202 / 8035)$ of visitors were studied.

Ms. Duffy had established a research protocol and had already collected data at the Old Faithful Visitor Education Center. The volunteers followed Ms. Duffy's protocol. Eight students from Stephen F. Austin State University were selected and used as data collectors. They were trained by Ms. Duffy in the data collection protocol and supervised by the professors with a graduate student, Ms. Sarah Fuller, selected as the lead volunteer assistant. The following is the protocol for data collection.

\section{Form}

Ms. Duffy created a data collection form used for the process. On the data collection form were three demographic questions: visitor's sex, age, and type of group. Once these data were recorded, next the volunteers recorded data pertaining to the total time at an exhibit, and ten questions related to activities at the exhibit:

- whether the person skipped the exhibit,

- whether the person skipped the exhibit with the exhibit occupied by one or more individuals,

- whether the person looked at the exhibit,

- whether the person read all or part of the information on the exhibit, 
- whether the person read aloud information on the exhibit,

- whether the person interacted with the exhibit,

- whether the person engaged in shared interaction at the exhibit,

- whether there was unintended interaction at the exhibit,

- whether one or more photos was taken of the exhibit,

- and whether there was any other behavior at the exhibit not previously identified.

If an individual was observed engaging in any of these activities, data collectors were to indicate the activity on the form. As the visitor left the exhibit, the time at the exhibit was noted and recorded on the form.

\section{Protocol}

Two days were selected for data collection: Friday, July $26^{\text {th }}$ and Saturday, July $27^{\text {th }}$. On Friday, students collected data from 9:30 a.m. to 4:00 p.m. for a total of 6.5 hours and on Saturday, July $27^{\text {th }}$ from 10:30 a.m. to $3: 30$ p.m. for a total of 5 hours. A total of 11.5 hours of data collection was used.

Students were dressed in normal, visitor attire and stationed at specifically selected points inside the Exhibit Hall where they could clearly observe the visitors without intruding upon, or influencing, the visitor experience. These locations were selected based on Ms. Duffy's recommendations and an on-site review of the exhibit area. Students were to maintain an unobtrusive appearance throughout the data collection time.

Following the data collection period, data were entered into an Excel spreadsheet and then copied into an SPSS data file for analysis. The data files were cleaned and some checks of data input accuracy were made. Data analysis was performed using standard statistical techniques in SPSS Version 21.

\section{$\downarrow \quad$ RESULTS}

\section{Observation results}

Observations were conducted during two consecutive days, Friday, July $26^{\text {th }}$ and Saturday, July $27^{\text {th }}, 2013$ by the researchers and research assistants. During July $26^{\text {th }}$, observations were made from 9:30 a.m. to 4:00 p.m. (total of 6.5 hours) and during July $27^{\text {th }}$ observations were made from 10:30 a.m. to $3: 30$ p.m. (total of 5 hours); total number of hours was 11.5. During this time, the OFVC was open for a total of 24 hours.

Every fifth person entering into the Exhibit Hall was observed. A total of 514 visitors were observed following the research protocol. Of those, $58.8 \%(\mathrm{n}=302)$ were observed on July $26^{\text {th }}$ and $41.2 \%$ $(n=212)$ were observed on July $27^{\text {th }}$ (Table 1$)$.

Table 1. Date of observation.

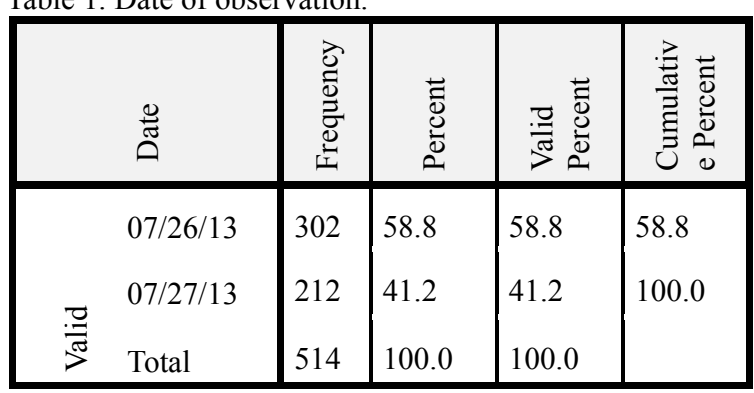

More visitors were observed in the afternoon (59.9\%) compared to the morning (40.1\%) (Table 2).

Table 2. Time of day of observation.

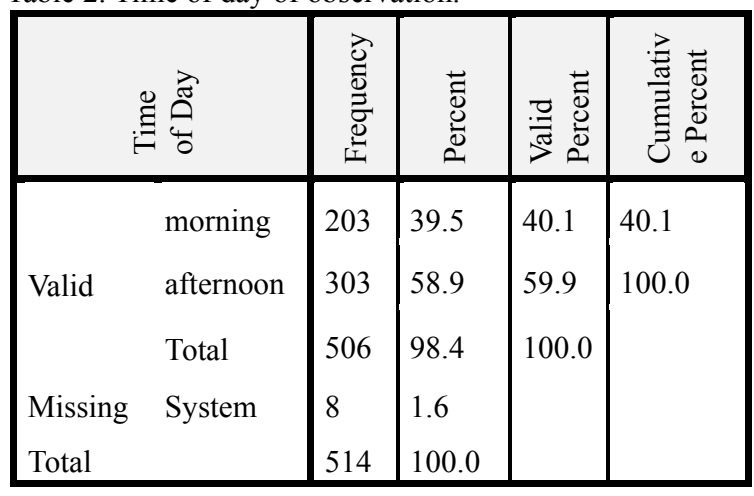

\section{Demographics of visitors}

The sex distribution was almost even with males representing $51.1 \%$ of visitors and females comprising $48.9 \%$ of visitors (Table 3 ).

Table 3. Sex of visitors.

\begin{tabular}{|c|c|c|c|c|c|}
\hline \multicolumn{2}{|c|}{ 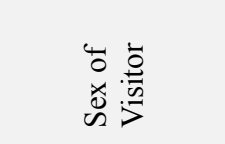 } & 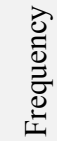 & 苛 & 可 & 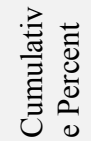 \\
\hline & female & 250 & 48.6 & 48.9 & 48.9 \\
\hline Valid & male & 261 & 50.8 & 51.1 & 100.0 \\
\hline & Total & 511 & 99.4 & 100.0 & \\
\hline Missing & $\begin{array}{l}\text { not } \\
\text { known }\end{array}$ & 3 & & & \\
\hline Total & & 514 & 100.0 & & \\
\hline
\end{tabular}


Age of visitor was estimated by each observer using eight age categories: 10-14, 15-19, 20s, $30 \mathrm{~s}, 40 \mathrm{~s}, 50 \mathrm{~s}, 60 \mathrm{~s}$, and 70 or older. Some one-quarter of visitors were 10 to 19 years old. The modal (typical) age of visitors was in the forties $(19.3 \%$ ) while $9.2 \%$ of visitors were in their 60 s or older (Table 4).

Table 4. Age of visitor.

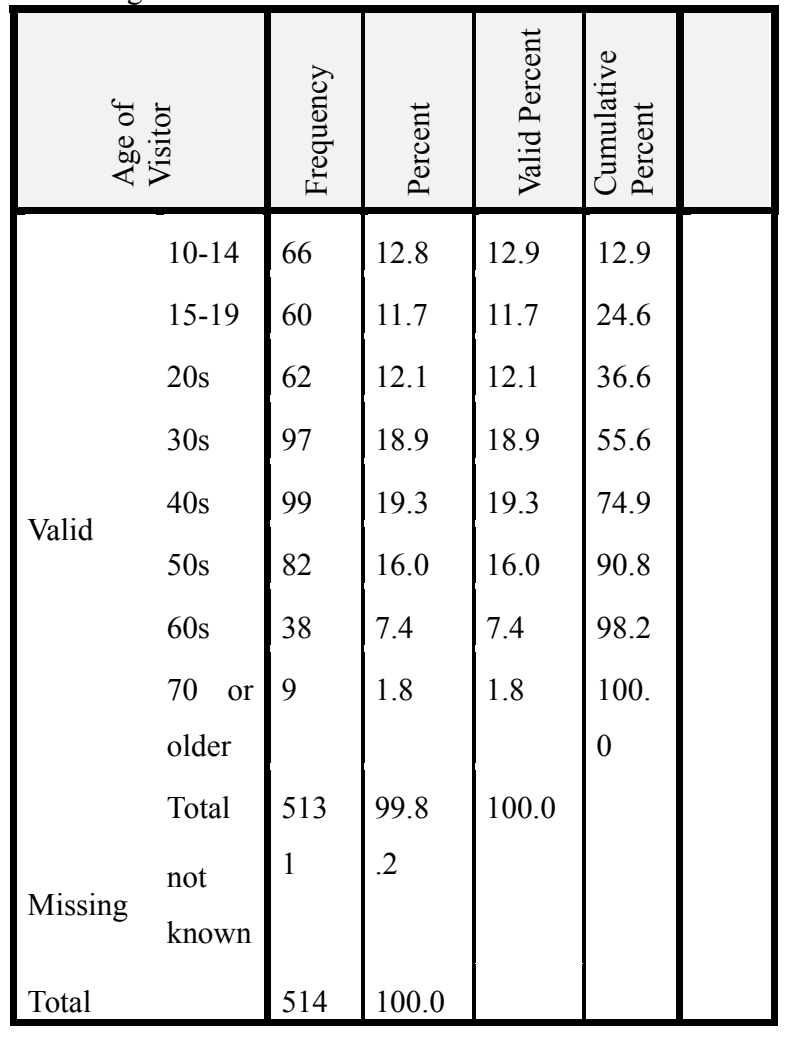

Individuals were observed in the context of their group make-up as they were moving through the exhibit hall. Groups were designed as one of the following: alone, multi, couple, family, or other. The distribution of groups is below. The most prevalent group type was family $(53.2 \%)$ while couples represented the next most common group type $(21.9 \%)$ (Table 5).

Age was cross-tabulated by sex to look at age distribution more closely. Despite the protocol of every fifth visitor being selected as they entered the hall, males were more likely to be observed than females among those 10-14, 20s, and 60s while females were more likely than males to be observed among those $15-19,30 \mathrm{~s}, 40 \mathrm{~s}, 50 \mathrm{~s}$, and 70 or older. However, the percent differences were relatively small and less than $5 \%$ for all age groups (Table 6).

In looking at whether time of day was related to group type, the cross tabulation revealed families and singles were more likely to be observed in the afternoon while the multi group and couples were more likely observed in the morning (Table 7).

Table 5. Type of group for visitors.

\begin{tabular}{|c|c|c|c|c|c|}
\hline & 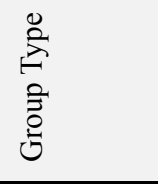 & 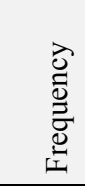 & 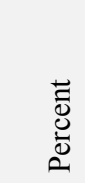 & 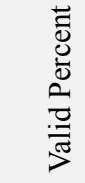 & 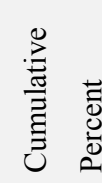 \\
\hline \multirow{6}{*}{ Valid } & alone & 96 & 18.7 & 18.8 & 18.8 \\
\hline & multi & 29 & 5.6 & 5.7 & 24.5 \\
\hline & couple & 112 & 21.8 & 21.9 & 46.4 \\
\hline & family & 272 & 52.9 & 53.2 & 99.6 \\
\hline & other & 2 & .4 & .4 & 100.0 \\
\hline & Total & 511 & 99.4 & 100.0 & \\
\hline Missing & not known & 3 & .6 & & \\
\hline Total & & 514 & 100.0 & & \\
\hline
\end{tabular}

Table 6. Age of visitor of sex of visitor.

\begin{tabular}{|c|c|c|c|c|}
\hline \multicolumn{2}{|c|}{ Age of Visitor } & \multicolumn{2}{|l|}{ Sex } & \multirow[t]{2}{*}{ Total } \\
\hline & & female & male & \\
\hline \multirow{2}{*}{$10-14$} & Count & 28 & 38 & 66 \\
\hline & $\%$ within Sex & $11.2 \%$ & $14.6 \%$ & $12.9 \%$ \\
\hline \multirow{2}{*}{$15-19$} & Count & 34 & 26 & 60 \\
\hline & $\%$ within Sex & $13.6 \%$ & $10.0 \%$ & $11.7 \%$ \\
\hline \multirow{2}{*}{$20 \mathrm{~s}$} & Count & 29 & 33 & 62 \\
\hline & $\%$ within Sex & $11.6 \%$ & $12.6 \%$ & $12.1 \%$ \\
\hline \multirow{2}{*}{$30 \mathrm{~s}$} & Count & 51 & 45 & 96 \\
\hline & $\%$ within Sex & $20.4 \%$ & $17.2 \%$ & $18.8 \%$ \\
\hline \multirow{2}{*}{$40 \mathrm{~s}$} & Count & 50 & 49 & 99 \\
\hline & $\%$ within Sex & $20.0 \%$ & $18.8 \%$ & $19.4 \%$ \\
\hline \multirow{2}{*}{$50 \mathrm{~s}$} & Count & 40 & 41 & 81 \\
\hline & $\%$ within Sex & $16.0 \%$ & $15.7 \%$ & $15.9 \%$ \\
\hline \multirow{2}{*}{$60 \mathrm{~s}$} & Count & 13 & 25 & 38 \\
\hline & $\%$ within Sex & $5.2 \%$ & $9.6 \%$ & $7.4 \%$ \\
\hline \multirow{2}{*}{$\begin{array}{l}70 \quad \text { or } \\
\text { older }\end{array}$} & Count & 5 & 4 & 9 \\
\hline & $\%$ within Sex & $2.0 \%$ & $1.5 \%$ & $1.8 \%$ \\
\hline \multirow{2}{*}{ Total } & Count & 250 & 261 & 511 \\
\hline & $\%$ within Sex & $100.0 \%$ & $100.0 \%$ & $100.0 \%$ \\
\hline
\end{tabular}


Table 7. Group type by time of day of observation.

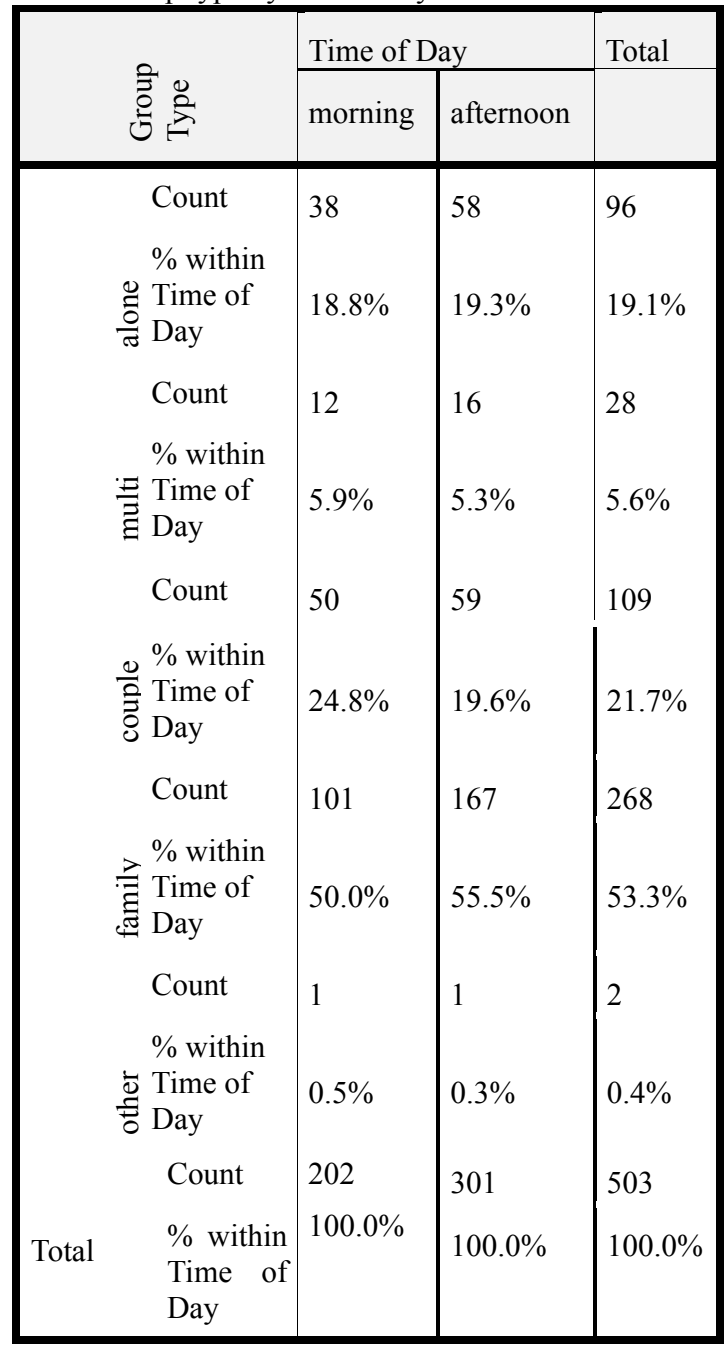

\section{Time spent at exhibits}

Researchers used stop-watches to observe the total time spent at each of the exhibits. For all visitors, the mean time was 1.4129 minutes (standard deviation $=1.59$ minutes), or about 85 seconds (standard deviation $=95$ seconds). Because of skewness, the median $(\mathrm{Md}=.88$ minutes $)$ may be the better measure of central tendency. The minimum recorded time was .02 minutes ( 1 second) while the maximum recorded time was 10.03 minutes, or 602 seconds. Some $75 \%$ of visitors were at the exhibits two minutes or less while $90 \%$ were at the exhibits 3.3 minutes or less (Table 8).

\section{Visitor activities at exhibits}

Below is a summary table that displays results from each of the exhibits (Table 9). The table shows the number of individuals observed who engaged in at least one activity for a particular exhibit, the mean number of activities observed (eight possible activities per exhibit) as well as the minimum number and the maximum number. In addition, the table displays the mean and standard deviation of times at each exhibit.

Table 8. Total time at exhibits.

\begin{tabular}{|c|c|c|c|}
\hline & & Statistic & Std. Error \\
\hline 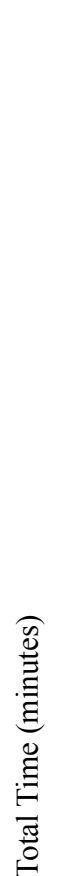 & $\begin{array}{l}\text { Mean } \\
95 \% \text { Lower } \\
\text { Confidence Bound } \\
\text { Interval for Upper } \\
\text { Mean } \\
5 \% \text { Trimmed Mean } \\
\text { Median } \\
\text { Variance } \\
\text { Std. Deviation } \\
\text { Minimum } \\
\text { Maximum } \\
\text { Range } \\
\text { Interquartile Range } \\
\text { Skewness } \\
\text { Kurtosis }\end{array}$ & $\begin{array}{l}1.4129 \\
1.2754 \\
1.5504 \\
1.2091 \\
.8800 \\
2.518 \\
1.58689 \\
.02 \\
10.03 \\
10.01 \\
1.70 \\
2.093 \\
5.388\end{array}$ & $\begin{array}{l}.108 \\
.215\end{array}$ \\
\hline
\end{tabular}

The number of visitors observed was 514 . Among these, there were 831 individual observations recorded, indicating that the average visitor stopped at about 1.5 exhibits while in the exhibit area. The number of observations varied by exhibit. More individuals were recorded at the diorama $(n=130)$ than any other exhibit while the rock exhibit had the fewest number of individuals $(\mathrm{n}=48)$.

Results show that 831 total observations were made during the data collection phase. The grand mean number of activities per exhibit was 1.56. Mean number of activities was the lowest at the rock exhibit while the above/below ground exhibit resulted in the highest mean number of activities $(\mathrm{M}=2.29)$.

Total time in minutes at each exhibit was recorded for each visitor. The grand mean was 2.44 minutes for all exhibits. Times at exhibit varied from a low of 0.92 minutes at the diorama to 3.07 minutes at the rock exhibit. 
Table 9. Descriptive statistics for exhibits.

\begin{tabular}{|c|c|c|c|c|c|c|}
\hline \multirow[t]{2}{*}{ 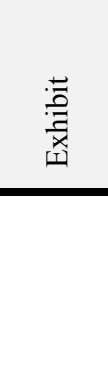 } & 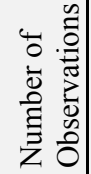 & \multicolumn{3}{|c|}{ 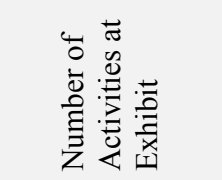 } & \multirow{2}{*}{ 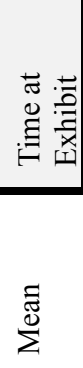 } & \\
\hline & & $\sum^{\Xi \Xi}$ & 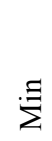 & $\sum_{\Sigma}^{x}$ & & 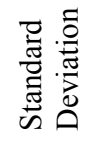 \\
\hline HT & 65 & 1.68 & 1 & 5 & 2.70 & 1.97 \\
\hline Gush & 56 & 1.29 & 1 & 3 & 2.79 & 1.90 \\
\hline Steam & 63 & 1.38 & 1 & 3 & 2.60 & 1.78 \\
\hline Hiss & 50 & 1.22 & 1 & 5 & 2.61 & 1.80 \\
\hline Bubble & 52 & 1.40 & 1 & 5 & 2.74 & 1.97 \\
\hline $\begin{array}{l}\text { Dioram } \\
\mathrm{a}\end{array}$ & 130 & 2.12 & 1 & 5 & 0.92 & 0.91 \\
\hline Volc & 65 & 1.55 & 1 & 3 & 2.79 & 2.27 \\
\hline Heat & 61 & 1.39 & 1 & 3 & 3.07 & 2.31 \\
\hline $\mathrm{H} 20$ & 52 & 1.46 & 1 & 5 & 3.01 & 2.26 \\
\hline Frac & 54 & 1.22 & 1 & 2 & 3.00 & 2.21 \\
\hline Rock & 48 & 1.19 & 1 & 3 & 3.07 & 2.21 \\
\hline $\begin{array}{l}\text { Above/ } \\
\text { Below } \\
\text { Ground }\end{array}$ & 68 & 2.29 & 1 & 5 & 1.12 & 1.17 \\
\hline $\mathrm{pH}$ & 67 & 2.09 & 1 & 4 & 1.33 & 1.22 \\
\hline Totals & 831 & 1.56 & 1 & 3.92 & 2.44 & 1.84 \\
\hline
\end{tabular}

The three demographic factors (sex, approximate age, group structure) were analyzed to determine if they significantly impacted total time at each of the exhibits. Thirty-nine One-Way ANOVA tests were conducted to examine the data for mean differences by sex, age, and group. Of the 39 tests, only one produced a significant outcome-total time at the Diorama Exhibit by group. Those having the longest time at the Diorama exhibit were those in multi-groups $(\mathrm{M}=1.78$ minutes $)$ and couples $(\mathrm{M}=$ 1.03) while those spending the least time there were those who appeared to be alone $(\mathrm{M}=0.75)$ (Table 10).

\section{$\uparrow \quad$ DISCUSSION}

It is obvious that use of the visitor center is not uniform throughout the day. Larger numbers of visitors do not arrive until 9 a.m. or so and by 4 p.m. the number of visitors in the visitor center has decreased dramatically from levels earlier in the day. Highest visitation appears to be during the mid-day hours of 10 a.m. to 3 p.m.
Table 10. ANOVA results of total time (in minutes) at the Diorama Exhibit by group.

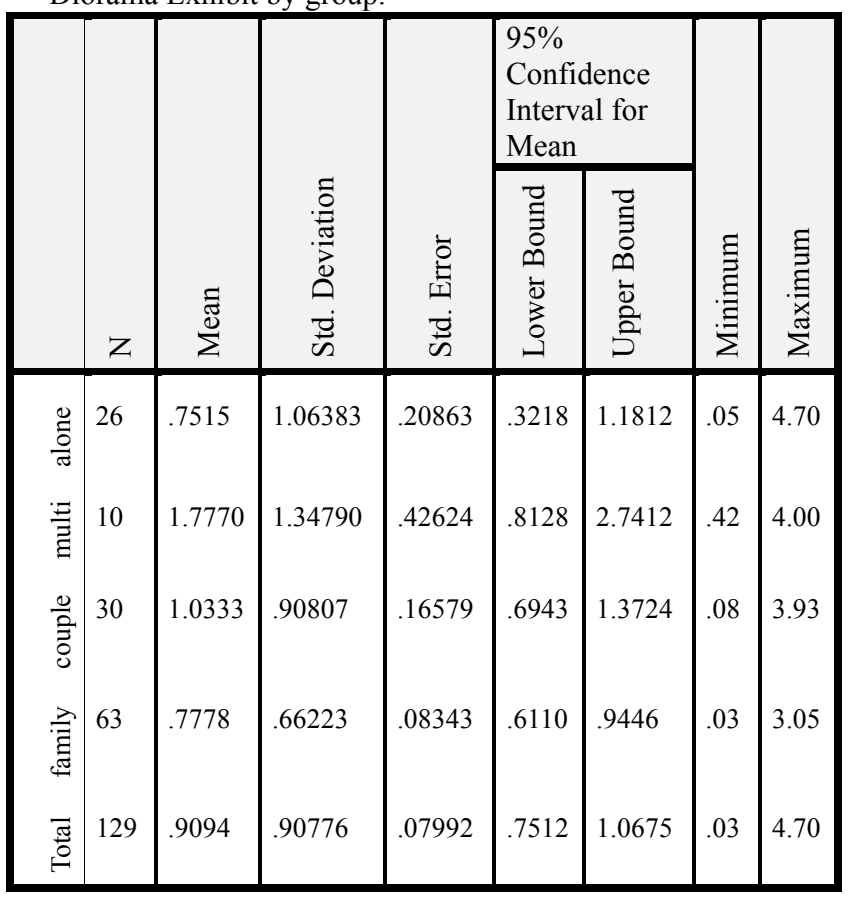

It is also obvious that use of the visitor center is a function of eruption times of Old Faithful. Immediately prior to and following an eruption, visitation of the exhibit area increased.

From the observations here there is some baseline information from which to build. There is now documented use by specific age groups and dynamics, times, and exhibits. A deeper look into the data here may give specific indications of what particular types of exhibits seem to draw specific audiences and engage them for what might be perceived as an accurate amount of time for them to clearly internalize the message of the exhibit. This information will help in the future design of exhibits and exhibit halls with specific audiences and intents in mind.

\section{YOUNG SCIENTIST! CHILDREN'S AREA}

\section{$\downarrow \quad$ RESULTS}

\section{Demographics}

Observers recorded data on 54 children while they were in the children's area. Of those 54 children, $31(57.4 \%)$ were boys and $23(42.6 \%)$ were girls (Table 11). 
Table 11. Sex of Child.

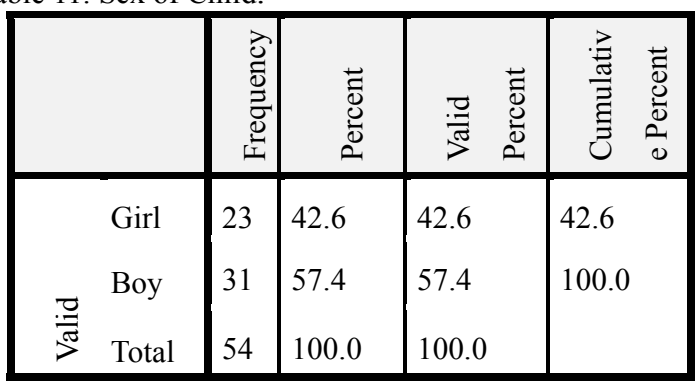

Age, using four age groups, of the child was estimated and recorded as well. About $9 \%$ were younger than kindergarten age. The modal category was kindergarten through $3^{\text {rd }}$ grade with $44.4 \%$ in this category. Those in the fourth through $8^{\text {th }}$ grade were the second most common (29.6\%) and about one-ofsix children (16.7\%) were in high school (Table 12).

Table 12. Age of Child.

\begin{tabular}{|c|c|c|c|c|c|c|c|}
\hline & & 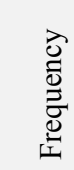 & 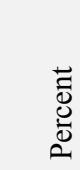 & $\frac{\overline{7}}{\frac{\pi}{\pi}}$ & 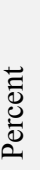 & 离 & 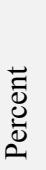 \\
\hline & Pre-K & 5 & 9.3 & 9.3 & & 9.3 & \\
\hline & K-3rd & 24 & 44.4 & 44.4 & & 53.7 & \\
\hline & 4th-8th & 16 & 29.6 & 29.6 & & 83.3 & \\
\hline . & 9th-12th & 9 & 16.7 & 16.7 & & 100.0 & \\
\hline$\overbrace{}^{\pi}$ & Total & 54 & 100.0 & 100.0 & & & \\
\hline
\end{tabular}

Researchers also recorded the type of group with which the children entered the children's area. Three group types were identified and recorded: alone, with single adult, or with family. Over $50 \%$ of children came to the area with their family. Another third came to the area with a single adult while $13 \%$ entered alone (Table 13).

Table 13. Group Type.

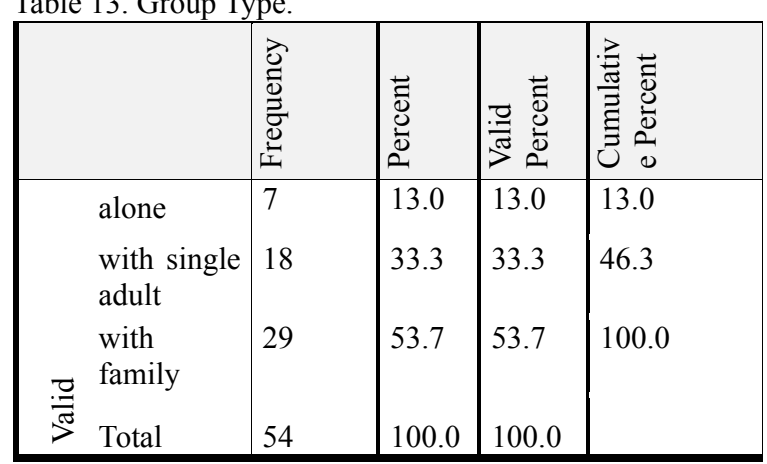

Lastly, the number of children in the group was noted; this included the child being observed. Two was the modal category $(40.7 \%$ ) while another $35.2 \%$ entered alone (Table 14).

\begin{tabular}{|c|c|c|c|c|c|}
\hline & & 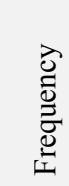 & $\begin{array}{l}\overrightarrow{0} \\
\text {. } \\
: 0 \\
0\end{array}$ & 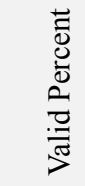 & 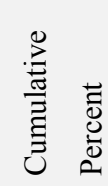 \\
\hline \multirow{6}{*}{$\frac{\pi}{\pi}$} & 1 & 19 & 35.2 & 35.2 & 35.2 \\
\hline & 2 & 22 & 40.7 & 40.7 & 75.9 \\
\hline & 3 & 9 & 16.7 & 16.7 & 92.6 \\
\hline & 4 & 3 & 5.6 & 5.6 & 98.1 \\
\hline & 5 & 1 & 1.9 & 1.9 & 100.0 \\
\hline & Total & 54 & 100.0 & & \\
\hline
\end{tabular}

Time in area

Once the child entered the children's area, time was recorded using a stopwatch until the child exited the area. Total time was recorded in seconds and in minutes. The results for the number of minutes the observed children were in the children's area are in the table below (Table 15). The mean time in the children's area was 3.63 minutes $(\mathrm{SD}=3.12$ minutes). The median was 2.83 minutes, which means that about half the children were there less than 2.83 minutes and about half were there more than 2.83 minutes. The minimum time was .13 minutes (or about 8 seconds) while the maximum time was 16.15 minutes. Ninety percent were in the area less than 7 minutes.

Total time in the children's area was examined using the demographic variables to determine if any of the variables explained variability in the time spent in the area. Sex of the child did exhibit some variability in average time: boys $(\mathrm{M}=$ 2.97) were in the area for a shorter time period than girls $(\mathrm{M}=4.52)$. However, the mean difference of 1.55 was not statistically significant at the 0.05 level $(\mathrm{p}=$. $07)$. Of note, the standard deviation for girls ( $\mathrm{SD}=$ 3.80) was well over one minute more than for boys $(\mathrm{SD}=2.33)$; this suggests that time in the area for boys was more consistent and less varied than for girls (Table 16). 
Table 15. Total Time in Young Scientist! Children's Area.

\begin{tabular}{|c|c|c|c|c|}
\hline \multicolumn{3}{|c|}{+2} & Statistic & $\begin{array}{l}\text { Std. } \\
\text { Error }\end{array}$ \\
\hline \multirow{15}{*}{ 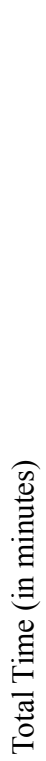 } & \multicolumn{2}{|l|}{ Mean } & 3.6287 & .42392 \\
\hline & $95 \%$ & Lower & 2.7784 & \\
\hline & Confidence & Bound & & \\
\hline & Interval for & Upper & 4.4790 & \\
\hline & Mean & Bound & & \\
\hline & \multicolumn{2}{|c|}{$5 \%$ Trimmed Mean } & 3.3221 & \\
\hline & \multicolumn{2}{|l|}{ Median } & 2.8333 & \\
\hline & \multicolumn{2}{|l|}{ Variance } & 9.704 & \\
\hline & \multicolumn{2}{|l|}{ Std. Deviation } & 3.11516 & \\
\hline & \multicolumn{2}{|l|}{ Minimum } & .13 & \\
\hline & \multicolumn{2}{|l|}{ Maximum } & 16.15 & \\
\hline & \multicolumn{2}{|l|}{ Range } & 16.02 & \\
\hline & \multicolumn{2}{|l|}{ Interquartile Range } & 3.58 & \\
\hline & \multicolumn{2}{|l|}{ Skewness } & 1.630 & .325 \\
\hline & \multicolumn{2}{|l|}{ Kurtosis } & 3.980 & .639 \\
\hline
\end{tabular}

Age also could influence the amount of time in the children's area. Pre-Kindergarten children had the longest average time in the area $(\mathrm{M}=3.93)$ while high schoolers had the shortest mean time $(\mathrm{M}=2.43)$. However, while there were mean differences by age group, the test for statistical significance was not significant at the .05 level $(\mathrm{p} .=.673)$ (Table 17).

Next, total time in the children's area was examined with group type. Children entering in a family group spent the longest total time $(\mathrm{M}=3.13$ minutes) while those alone had the shortest mean time in the children's area ( $\mathrm{M}=1.14$ minutes). The OneWay ANOVA test for significance of mean differences was not significant at the .05 level $(\mathrm{p}=0.069)$ (Table $18)$.

Table 16. Total time in children's area by sex.

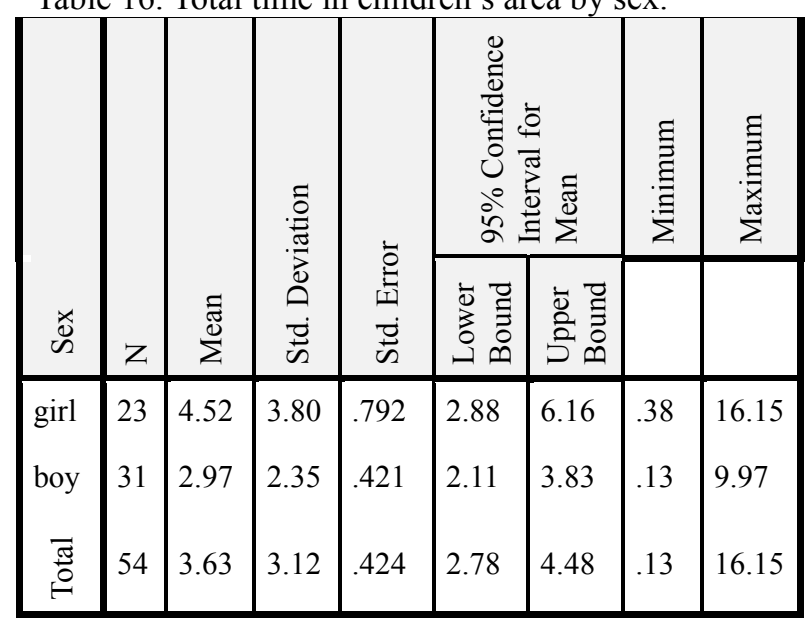

Table 17. Total time in children's area by age group.

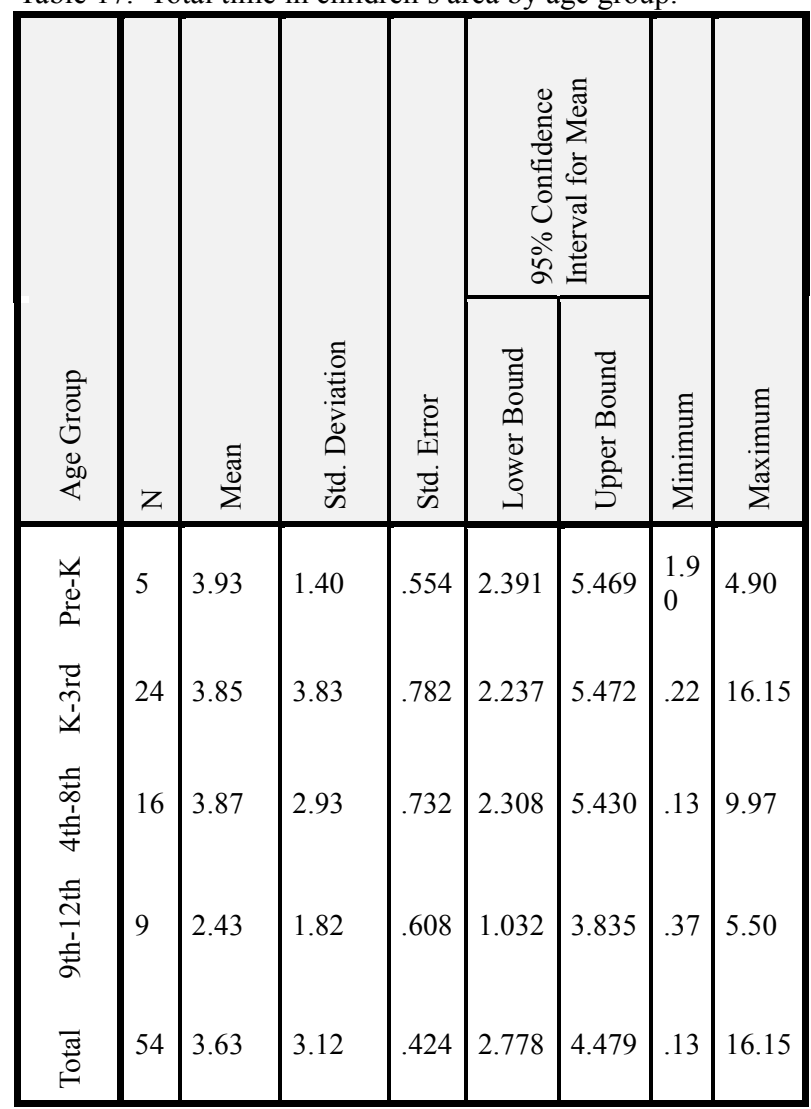

Table 18. Total Time (in minutes) in children's area by group type.

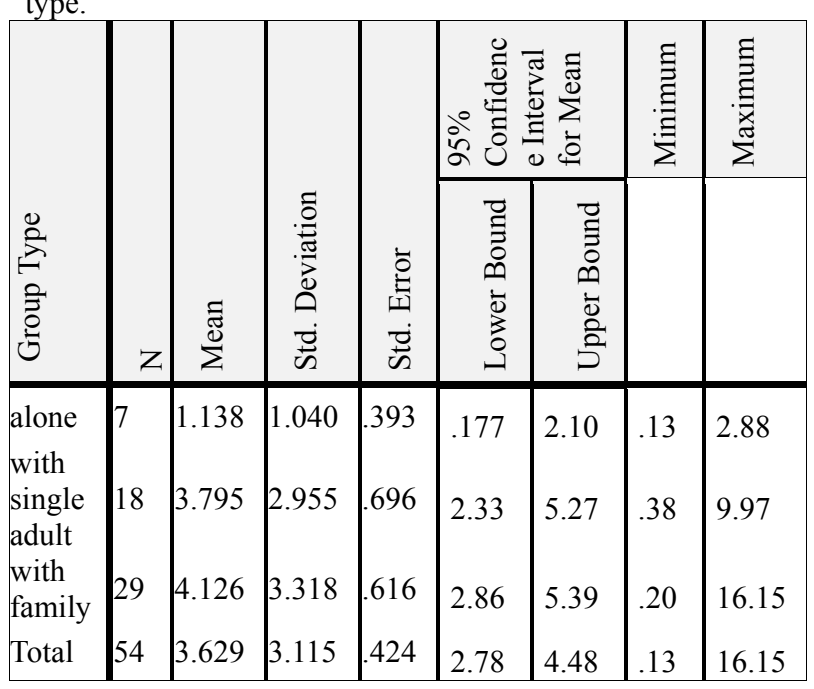

Last, total time in the area was analyzed by number of children in the group. Results were statistically significant $(\mathrm{p} .=.024)$. Those who were in the children's area alone spent significantly less time, on average, in the area $(\mathrm{M}=2.00$ minutes) compared to those who were in a group of three children (5.33 minutes) (Table 19). 
Table 19. Total time in children's area by number of children.

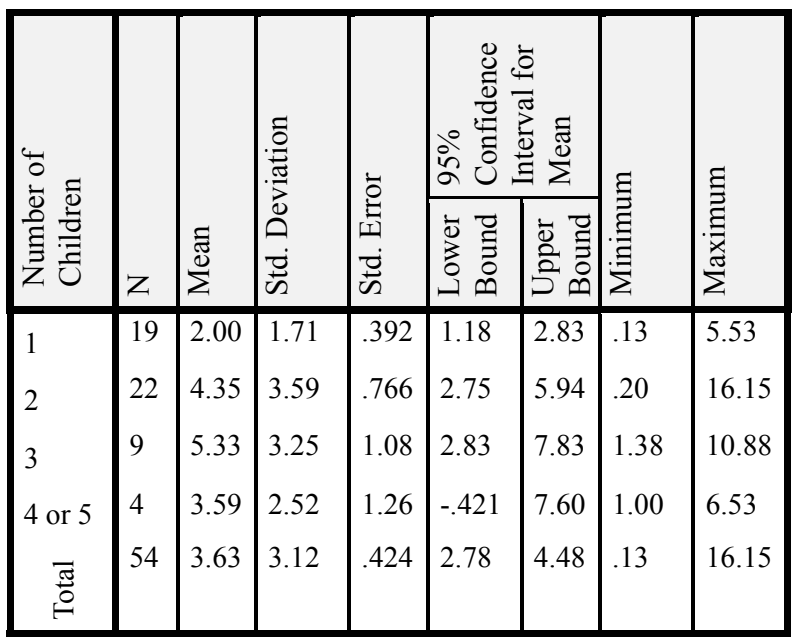

Individual exhibits

The table below shows the percentage (rounded to the nearest whole percentage) of children who entered the Young Scientist! area and their participation in the nine behaviors for each of the eleven exhibits (which includes the junior ranger station located in the near right corner of the room) (Table 20).

Only the observing and geyser model exhibit drew participation by over half of all children. Some $80 \%$ of children went to the observing exhibit and $76 \%$ of children went to the geyser model exhibit. The exhibits most likely skipped were the "Is It True?" exhibit with $82 \%$ skipping it and the ID Wildlife exhibit with $80 \%$ skipping it. The mean for all exhibits was $61 \%$ skipped.
Very few children skipped exhibits while exhibits were occupied; this occurred for only two exhibits (ID Wildlife and Predicting Geysers).

The most read exhibits were the Geyser Model (15\%), Predicting Geysers (13\%), and the Is it True? (11\%). All other exhibits had fewer than $10 \%$ of children doing any reading. Reading aloud was less prevalent than reading to one's self (as might be expected). Reading aloud was observed for only three exhibits (Observing, Is It True?, and Geyser Model), each of which had $2 \%$.

Interaction was observed for all eleven exhibits with an average of $19 \%$ across all exhibits. Interaction varied by exhibit, ranging from a high of $56 \%$ for the Observing exhibit to a low of $6 \%$ for the Young Scientist Trivia and Geyser Model exhibits. On average, shared interaction occurred $6 \%$ of the time. Observing had the highest amount of shared interaction (26\%). Animal Tracks (9\%), Geyser Model (7\%), and Jr. Ranger (7\%) had some shared interaction, too.

Behaviors were cross-tabulated with the demographic variables to determine if any statistical significant patterns existed. Results of all tests are shown below in the table (Table 21). Significant relationships are identified and the characteristic of the demographic variable with the highest frequency of that particular behavior is identified. For example, the relationship between skipped and sex was significant and furthermore, results indicate that boys were more likely to skip the junior ranger station than girls.

Table 20. Percentages of children at each exhibit engaging in selected behaviors.

\begin{tabular}{|l|l|l|l|l|l|l|l|l|l|}
\hline Exhibit Name & Skipped & $\begin{array}{l}\text { Skipped, } \\
\text { Occupied }\end{array}$ & Read & Looked & $\begin{array}{l}\text { Read } \\
\text { Aloud }\end{array}$ & Interact & $\begin{array}{l}\text { Shared } \\
\text { Interaction }\end{array}$ & $\begin{array}{l}\text { Unintended } \\
\text { Interaction }\end{array}$ & $\begin{array}{l}\text { Photo } \\
\text { Taken }\end{array}$ \\
\hline Observing & $20 \%$ & $0 \%$ & $9 \%$ & $43 \%$ & $2 \%$ & $56 \%$ & $26 \%$ & $0 \%$ \\
\hline Layers of Life & $69 \%$ & $0 \%$ & $4 \%$ & $24 \%$ & $0 \%$ & $7 \%$ & $4 \%$ & $0 \%$ \\
\hline Young Scientist Trivia & $78 \%$ & $0 \%$ & $9 \%$ & $19 \%$ & $0 \%$ & $6 \%$ & $4 \%$ & $0 \%$ \\
\hline Is it True? & $82 \%$ & $0 \%$ & $11 \%$ & $6 \%$ & $2 \%$ & $15 \%$ & $2 \%$ & $0 \%$ & $0 \%$ \\
\hline Stage & $65 \%$ & $0 \%$ & $0 \%$ & $17 \%$ & $0 \%$ & $28 \%$ & $2 \%$ & $0 \%$ & $0 \%$ \\
\hline Eating Silica & $56 \%$ & $0 \%$ & $7 \%$ & $32 \%$ & $0 \%$ & $22 \%$ & $6 \%$ & $0 \%$ \\
\hline Animal Tracks & $67 \%$ & $0 \%$ & $9 \%$ & $22 \%$ & $0 \%$ & $19 \%$ & $9 \%$ & $0 \%$ & $0 \%$ \\
\hline ID Wildlife & $80 \%$ & $2 \%$ & $0 \%$ & $13 \%$ & $0 \%$ & $7 \%$ & $0 \%$ & $0 \%$ \\
\hline Predicting Geysers & $67 \%$ & $4 \%$ & $13 \%$ & $20 \%$ & $0 \%$ & $19 \%$ & $1 \%$ & $0 \%$ & $0 \%$ \\
\hline Geyser Model & $24 \%$ & $0 \%$ & $15 \%$ & $70 \%$ & $2 \%$ & $6 \%$ & $7 \%$ & $0 \%$ \\
\hline Jr. Ranger & $63 \%$ & $0 \%$ & $2 \%$ & $19 \%$ & $0 \%$ & $22 \%$ & $7 \%$ & $0 \%$ & $0 \%$ \\
\hline Mean & $61 \%$ & $1 \%$ & $7 \%$ & $26 \%$ & $1 \%$ & $19 \%$ & $6 \%$ & $0 \%$ \\
\hline
\end{tabular}


Table 21. Relationships between demographic variables and behaviors in children's area.

\begin{tabular}{|c|c|c|c|c|}
\hline Behavior & Sex & Age & Group Type & Number of Children \\
\hline Skipped & $\begin{array}{l}\text { Junior Ranger } \\
\text { (boys more likely } \\
\text { to skip than girls) }\end{array}$ & $\begin{array}{l}\text { Junior Ranger (most likely to } \\
\text { skip were high schoolers and } \\
\text { least likely to skip were pre- } \\
\text { schoolers) }\end{array}$ & $\begin{array}{l}\text { No significant } \\
\text { relationships }\end{array}$ & $\begin{array}{l}\text { No significant } \\
\text { relationships }\end{array}$ \\
\hline $\begin{array}{l}\text { Skipped, } \\
\text { Occupied }\end{array}$ & $\begin{array}{l}\text { No significant } \\
\text { relationships }\end{array}$ & No significant relationships & $\begin{array}{l}\text { No significant } \\
\text { relationships }\end{array}$ & $\begin{array}{l}\text { No significant } \\
\text { relationships }\end{array}$ \\
\hline Read & $\begin{array}{l}\text { Animal Tracks } \\
\text { (boys more likely } \\
\text { than girls) }\end{array}$ & $\begin{array}{l}\text { Is it true? (Children in } 4^{\text {th }}- \\
8^{\text {th }} \text { grade more likely); } \\
\text { Eating Silica (Children in } 4^{\text {th }} \\
-8^{\text {th }} \text { grade more likely) } \\
\text { Geyser Model (Children in } \\
4^{\text {th }}-8^{\text {th }} \text { grade most likely) }\end{array}$ & $\begin{array}{l}\text { Is it true? } \\
\text { (Children with } \\
\text { single adults more } \\
\text { likely) }\end{array}$ & $\begin{array}{l}\text { No significant } \\
\text { relationships }\end{array}$ \\
\hline Looked & $\begin{array}{l}\text { No significant } \\
\text { relationships }\end{array}$ & No significant relationships & $\begin{array}{l}\text { No significant } \\
\text { relationships }\end{array}$ & $\begin{array}{l}\text { No significant } \\
\text { relationships }\end{array}$ \\
\hline Read Aloud & $\begin{array}{l}\text { No significant } \\
\text { relationships }\end{array}$ & No significant relationships & $\begin{array}{l}\text { No significant } \\
\text { relationships }\end{array}$ & \\
\hline
\end{tabular}

\begin{tabular}{|l|l|l|l|l|}
\hline Interact & $\begin{array}{l}\text { No significant } \\
\text { relationships }\end{array}$ & $\begin{array}{l}\text { Observing (Pre-K children } \\
\text { more likely); Animal Tracks } \\
\text { (Pre-K children more likely) }\end{array}$ & $\begin{array}{l}\text { ID Wildlife } \\
\text { (Children with } \\
\text { single adult more } \\
\text { likely) }\end{array}$ & $\begin{array}{l}\text { No significant } \\
\text { relationships }\end{array}$ \\
\hline $\begin{array}{l}\text { Shared } \\
\text { Interaction }\end{array}$ & $\begin{array}{l}\text { No significant } \\
\text { relationships }\end{array}$ & No significant relationships & $\begin{array}{l}\text { No significant } \\
\text { relationships }\end{array}$ & $\begin{array}{l}\text { Junior Ranger (Children } \\
\text { in groups of three } \\
\text { children more likely) }\end{array}$ \\
\hline $\begin{array}{l}\text { Unintended } \\
\text { Interaction }\end{array}$ & None observed & None observed & None observed & None observed \\
\hline Photo Taken & None observed & None observed & None observed & None observed \\
\hline Other & None observed & None observed & None observed & None observed \\
\hline
\end{tabular}

